\title{
Hydrogen sulphide, an avant-garde potential virulence factor of Mycoplasma bovis isolated from the lungs of the Camelus dromedarius exhibiting silent pneumonia: Virulence, antimicrobial resistance and phylogeny
}

\author{
Walaa Abd elazeem ${ }^{1}$, Zeinab Mohammed ${ }^{1}$, Alaa Saad ${ }^{1}$, Heba Deif ${ }^{1}$, and kamelia osman ${ }^{2}$ \\ ${ }^{1}$ Affiliation not available \\ ${ }^{2}$ Cairo University, Faculty of Veterinary Medicine
}

September 11, 2020

\begin{abstract}
The impact of asymptomatic carriers on the survival of Mycoplasma bovis in the environment and the role of wildlife in transmitting M. bovis still requires to be extensively studied. In this study, we have extended the arsenal of factors implicated in pathogenicity of M. bovis to shed light on the current knowledge gap. A number of 460 lung samples (pneumonic; n=210 and apparently healthy; $\mathrm{n}=250$ ) were randomly collected from one hundred humped camels (Camelus domedarius). Biochemically, $13 / 210$ of the recovered isolates $(27.3 \%)$ from the pneumonic lungs were recorded as putative mycoplasmas and to be confirmed by PCR to be M. bovis. Infection with M. bovis was not detected in the apparently healthy lungs. They were examined for their phenotypic virulence traits and antimicrobial resistance. Haemolysis and hydrogen sulphide (H2S) production was evident in $100 \%$ of the isolates. All $13 \mathrm{M}$. bovis isolates were weak in their ability to form biofilm on polystyrene surfaces and were $100 \%$ susceptible to florfenicol, spiromycin and streptomycin while 100\% resistant to ciprofloxacin. Five different combinations of antibiotics representing one to three classes with the Macrolide erythromycin being the most represented. Surprisingly, we did not detect the uvrC and gapA virulence genes by PCR, however we did detect the vsp gene in 2 out of 13 isolates. In addition, we detected the parC gene encoding quinolone resistance in 2 out of $13 \mathrm{M}$. bovis isolates, but did not detect the gyrA gene. Moreover, we have showed H2S, a compound that has previously not been identified as a virulence factor in M. bovis.
\end{abstract}

Hydrogen sulphide, an avant-garde potential virulence factor of Mycoplasma bovis isolated from the lungs of the Camelus dromedarius exhibiting silent pneumonia: Virulence, antimicrobial resistance and phylogeny

Walaa Mohammed Abd elazeem

Mycoplasma Department, Animal Health Research Institute, Egypt

e-mail: lolo3006@yahoo.com

\section{Zeinab Roshdy Mohammed}

Mycoplasma Department, Animal Health Research Institute, Egypt

e-mail: zeinabmony@gmail.com

\section{Alaa Saad}

Department of Poultry Diseases, Animal Health Research Institute,Giza, Egypt 
e-mail: alaasamir87@yahoo.com

\title{
Heba N Deif
}

Department of Microbiology, Faculty of Veterinary Medicine, Cairo University, Egypt

e-mail: naimheba@yahoo.com

Kamelia M Osman ${ }^{1} *$,

${ }^{1}$ Department of Microbiology, Faculty of Veterinary Medicine, Cairo University, Egypt

*Corresponding authore-mail: kamelia-osman@hotmail.com

\begin{abstract}
The impact of asymptomatic carriers on the survival of Mycoplasma bovis in the environment and the role of wildlife in transmitting $M$. bovis still requires to be extensively studied. In this study, we have extended the arsenal of factors implicated in pathogenicity of $M$. bovis to shed light on the current knowledge gap. A number of 460 lung samples (pneumonic; $n=210$ and apparently healthy; $n=250$ ) were randomly collected from one hundred humped camels (Camelus domedarius). Biochemically, 13/210 of the recovered isolates $(27.3 \%)$ from the pneumonic lungs were recorded as putative mycoplasmas and to be confirmed by PCR to be $M$. bovis . Infection with $M$. bovis was not detected in the apparently healthy lungs. They were examined for their phenotypic virulence traits and antimicrobial resistance. Haemolysis and hydrogen sulphide $\left(\mathrm{H}_{2} \mathrm{~S}\right)$ production was evident in $100 \%$ of the isolates. All $13 \mathrm{M}$. bovis isolates were weak in their ability to form biofilm on polystyrene surfaces and were $100 \%$ susceptible to florfenicol, spiromycin and streptomycin while $100 \%$ resistant to ciprofloxacin. Five different combinations of antibiotics representing one to three classes with the Macrolide erythromycin being the most represented. Surprisingly, we did not detect the uvr C and gap A virulence genes by PCR, however we did detect the vspgene in 2 out of 13 isolates. In addition, we detected the par $\mathrm{C}$ gene encoding quinolone resistance in 2 out of $13 \mathrm{M}$. bovisisolates, but did not detect the gyr A gene. Moreover, we have showed $\mathrm{H}_{2} \mathrm{~S}$, a compound that has previously not been identified as a virulence factor in $M$. bovis .
\end{abstract}

Keywords: Camel; Mycoplasma bovis ; Virulence genes; Antibiotic resistance; Hydrogen sulphide; biofilm

\section{Introduction}

The dromedary (Camelus dromedarius or one-humped camel), named in 1758 by the Swedish zoologist Carl Linnaeus (Linnaeus, 1758), is one of a half-dozen of camel species left on the planet, including llamas, alpacas, vicunas, and guanacos in South America, as well as its cousin, the two-humped Bactrian camel in Asia (Hirst, 2020). All evolved from a common ancestor some 40-45 million years ago in North America (Hirst, 2020). Archaeological evidence for early dromedary use, includes the predynastic site of Qasr Ibrim, in Egypt (Hirst, 2020), where camel dung was identified about 900 BC, and because of its location interpreted as dromedary. Dromedaries, did not become ubiquitous in the Nile Valley until about 1,000 years later (Hirst, 2020). Nowadays, the camels reach Egypt in herds through the continuous importation, mainly from 
Chad, Sudan, Ethopia, Eritria, Somalia and Libya becoming a crucial cause of transmission of infectious diseases (Roess et al., 2015; Napp et al., 2018).

Mycoplasma bovis is a wall-less bacterium, which is considered one of the most pathogenic species of the genus Mycoplasma in the family of Mycoplasmataceae within the Class Mollicutes (Brown et al., 2015). To date there have been few studies investigating mycoplasmosis in camel species caused by $M$. bovis although it is an important cause of respiratory disease and mastitis in cattle throughout the world, and often is reported as emerging (Gille et al., 2018). While M. bovis is not a risk for food safety (Nigel French, 2019), it can cause a disease that affects animal welfare, sustainable food production and the farming economy. Consequently, M. bovis is one of the major pathogens of biosecurity significance to a dairy herd, due to its highly contagious nature and tendency to be chronic, debilitating and unresponsive to antimicrobial therapy (Fox, 2012). In Africa, camels live as free ranging animals and there are no official restrictions on animal movement between the African countries; a situation also seen within the European Union (EU) with cattle (Calcutt et al., 2018).

In vitro phenotypes linked to the virulence of $M$. bovis strains isolated from camels have not yet been described despite its pathogenic potential which has been evidenced in several studies (Nicholas and Ayling, 2003). Großhennig et al. (2016) and Osman et al. (2020) shared results confirming $\mathrm{H}_{2} \mathrm{~S}$ production and haemolysis were correlated in $M$. pneumonia and M. arginini. In this study we carried out a knowledge gap analysis, by the assessment of $\mathrm{H}_{2} \mathrm{~S}$ production by $M$. bovis as a potential virulence factor in addition to the haemolytic activity; its ability to produce biofilm and identification of two genes responsible for quinolone resistance (QRDR). We have also investigated whethervsp -related DNA sequences also occur in M. bovis camel isolates.

\section{Materials and methods}

\section{Sample collection}

A total of 460 samples were randomly been recovered from pneumonic $(n=210)$ and apparently healthy ( $n=250)$ lungs of imported one humped camels during February to April 2018. The animals were submitted for routine slaughter. For the purpose of this study' pneumonic lungs' was referred to those lungs that had gross lesions such as consolidation, fibrin deposition on the pleura, pleurisy, and/or adhesion; while 'apparently healthy lungs' was used to describe those without any gross lesions. Specimens were obtained aseptically while taking precautions to prevent surface contamination. Following collection, the samples were transported to the microbiology laboratory in special ice-filled containers within $2 \mathrm{~h}$ of sampling. Primary isolation of mycoplasmas from lung samples was performed in liquid medium using pleuropneumonia-like organism broth and agar media (PPLO; Difco, Fisher Scientific, Waltham, MA, USA). Purified isolates were maintained on PPLO agar media. Preliminary identification of the isolates was performed based on colony morphology as examined under stereo-microscope (Leitz, Germany), to scan the surface of the medium to visualize the colonies. Digitonin sensitivity test was carried out to differentiate between Mycoplasma and Acholeplasma genera using filter paper discs impregnated with $0.2 \mathrm{~mL}$ of $1.5 \%$ (W/V) ethanol solution of digitonin and dried overnight. Mycoplasma spp. show digitonin sensitivity while Acholeplasma spp. are resistant (Freundt et al., 1973). Biochemical identification was used for further testing of Mycoplasma spp. Glucose fermentation, arginine deamination and urea hydrolysis tests were performed as described previously (Erno and Stipkovits, 1973; Howard et al., 1994). Serological confirmation of Mycoplasma spp. was additionally conducted as described by Clyde (1964), while the species-specific identification was performed with anti- $M$. bovis hyperimmune serum (Lauerman et al., 1994) by the growth inhibition test utilizing dried antiserum impregnated paper discs. Standard antisera were used as control,M. bovis PG45, M. bovirhinis PG43 and M. argininiG230. Final identification of the isolates was achieved by PCR.

\section{Phenotypic virulence traits}

\section{Catalase enzyme activity}

Cells from mid-log phase cultures of $M$. bovis transformants were collected by centrifugation at 20,000x $g$ for 
20 min and washed three times with cold phosphate-buffered saline (PBS). Cells were smeared onto a clean microscope slide and one drop of $3 \% \mathrm{H}_{2} \mathrm{O}_{2}$ was added. Catalase activity was indicated by the generation of bubbles (Pritchard et al., 2014).

\section{Assay for haemolytic activity}

Haemolytic and haemoxidative activity of $M$. bovis was determined as described previously (Grosshennig et al., 2016). Briefly, harvested $M$. bovis cells were resuspended in PBS and added to washed sheep RBCs (final concentration: $2 \%$ in PBS) with, or without, supplements in a final volume of $1 \mathrm{ml}$. Aliquots without cells served as control. The test samples were incubated in a rotary shaker at 110 r.p.m. and $37^{\circ} \mathrm{C}$ for time periods. After 10 min centrifugation at $48^{\circ} \mathrm{C}$ and $1400 x g$, the supernatant was transferred into a new tube

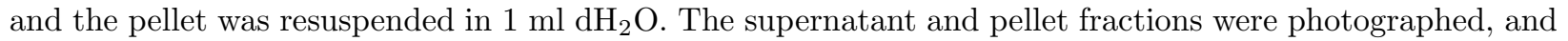
their spectra were recorded from 370 to $700 \mathrm{~nm}$.

\section{Determination of in vitro hydrogen sulphide production}

The $\mathrm{H}_{2} \mathrm{~S}$ produced by the $13 \mathrm{M}$. bovis isolates was determined using lead acetate detection strips as previously described (Grosshennig et al.,2016). Briefly, growing cells were harvested and resuspended in 1ml 1x PBS ( $\mathrm{pH}$ 7.4) supplemented with L-cysteine. Sterile filter paper strips impregnated with lead acetate were affixed

to the inner wall of the test tubes above the level of the liquid culture. An aliquot without L-cysteine served as the control. After $18 \mathrm{~h}$ of incubation at $37^{\circ} \mathrm{C}$, the test strips were read and photographed.

\section{Analysis of biofilm growth}

Crystal violet staining was performed as described previously (McAuliffe et al., 2006). Biofilms grown on glass coverslips and in microtitre plates were rinsed briefly in PBS to remove non-adherent cells and stained with $0.5 \%$ crystal violet solution for 30 min. Biofilms were then washed profusely in $\mathrm{dH}_{2} \mathrm{O}$ before being left to dry at room temperature for $30 \mathrm{~min}$. Coverslips were broken into smaller pieces using sterile forceps and $1 \mathrm{ml} \mathrm{100 \%}$ ethanol was added to solubilize the crystal violet. Solubilization of the crystal violet in stained biofilms was implemented by adding $200 \mathrm{ml}$ of $100 \%$ ethanol onto the microtitre plates. Biofilm production was quantified by measuring the absorbance $(560 \mathrm{~nm})$ of $100 \mathrm{ml}$ of the solubilized crystal violet in a microtitre plate.

\section{Antibiotic susceptibility test}

The $13 \mathrm{M}$. bovis isolates were tested for susceptibility to eight antimicrobial agents by the disc diffusion method. The antimicrobial agents used in this study included: Fluoroquinolone:ciprofloxacin (5 ug); Macrolides: spiramycin (100 ug), tylosin (30 ug) and erythromycin (15 ug); Phenicol: florfenicol (30 ug); Aminoglycoside: streptomycin (10ug); Lincosamide:lincomycin (2 ug); Tetracycline: doxycycline (30 ug) according to the procedures outlined in CLSI (2012). The type strain M. bovis ATCC 25523/ PG45 was used as quality control

\section{Molecular Identification}

\section{DNA extraction}

Isolates that only reacted with $M$. bovis antisera were selected. The bacterial lysates used as templates for the PCR were prepared as follows: A loopful of bacteria from a fresh overnight culture on a tryptic soy agar plate (Difco, Detroit, MI, USA) was re-suspended homogeneously in $200 \mu l$ of sterile water, and the mixture was boiled at $100^{\circ} \mathrm{C}$ for $5 \mathrm{~min}$ to release the DNA and centrifuged. The supernatant was used as a template for PCR mixture. Confirmation of these isolates as species of $M$. bovis was achieved using two PCR-based assays: 1) PCR products were generated from each isolate using primers that amplify a $16 \mathrm{~S}$ rRNA sequence specific for Mycoplasmaspecies (Yleana et al., 1995); 2) then the Mbo gene was amplified using MboF/MboR primers which is a confirmation of M. bovis(Subramaniam et al., 1998) (Table 1). 
The DNA of the $M$. bovis type strain ATCC 25523/ PG45 served as a positive control, while nuclease free water was used as negative control.

\section{S rRNA identification of camel Mycoplasma}

Positive isolates were further confirmed for mycoplasmas by PCR amplification of the 16S rRNA gene using Mycoplasma specific primers (Table 1). PCR reaction was performed in a $50 \mu$ l volume for each isolate, consisting of $5 \mu \mathrm{l}$ of $50 \mathrm{ng}$ of Mycoplasma DNA, $10 \mu \mathrm{l}$ of $10 \mathrm{x}$ Taq buffer $(10 \mathrm{mM}$ tris- $\mathrm{HCl}$ [pH 8.8], $50 \mathrm{mM} \mathrm{KCl}$ ), $1 \mu \mathrm{l}$ of $50 \mathrm{pM}$ of forward and reverse primers, $1.5 \mathrm{mM} \mathrm{MgCl}_{2}, 1 \mu \mathrm{l}$ of $2 \mathrm{U}$ of Taq polymerase, $1 \mu \mathrm{l}$ of $50 \mathrm{uM}$ of each dNTP, and $31 \mu \mathrm{l}$ of DNase- RNase- free, deionized water. The PCR reaction was performed in a thermal cycler (Biometra TRIO, Jena, Germany) with an intial denaturation at $94^{\circ} \mathrm{C}$ for 5 min., followed by 35 cycles of denaturation at $94^{\circ} \mathrm{C}$ for $1 \mathrm{~min}$, annealing at $55^{\circ} \mathrm{C}$ for $1 \mathrm{~min}$., and extension at $72^{\circ} \mathrm{C}$ for $1.5 \mathrm{~min}$ with a final extention at $72^{\circ} \mathrm{C}$ for $10 \mathrm{~min}$.

\section{S rRNA identification of Mycoplasma species using Mycoplasma group-specific primers set}

The same procedure for $16 \mathrm{~S}$ rRNA PCR reaction as described above was used for Mycoplasma species identification, but using the following PCR conditions: 40 cycles of denaturation at $94^{\circ} \mathrm{C}$ for one minute, annealing at $55^{\circ} \mathrm{C}$ for $1 \mathrm{~min}$ and extension at $72^{\circ} \mathrm{C}$ for $2 \mathrm{~min}$.

\section{Mycoplasma bovis typing}

Positive M. bovis isolates were further confirmed by PCR reaction. The PCR conditions for this reaction were denaturation at $94^{\circ} \mathrm{C}$ for 45 seconds, primer annealing at $60^{\circ} \mathrm{C}$ for $1 \mathrm{~min}$., and extension at $72^{\circ} \mathrm{C}$ for 2 min. The reactions were performed for 30 or 35 cycles with a final extention at $72^{\circ} \mathrm{C}$ for $3 \mathrm{~min}$.

\section{Detection of virulence genes}

PCR was performed to detect three virulence genes of $M$. bovis, including the variable surface lipoprotein gene (vsp), cytadhesin ( gap A) and the uvr $\mathrm{C}$ which encodes a protein involved in DNA excision and repair using the primers as described previously (Table 1 ). PCR reactions were performed in a $20 \mu \mathrm{l}$ volume for each isolate as describe above. The PCR condition for detection of the vsp gene was initial denaturation at $94^{\circ} \mathrm{C}$ for $5 \mathrm{~min}$, followed by 35 cycles of denaturation at $94^{\circ} \mathrm{C}$ for $1 \mathrm{~min}$, annealing at $55^{\circ} \mathrm{C}$ for $1 \mathrm{~min}$, and extension at $72^{\circ} \mathrm{C}$ for 1.5 min with a final extension at $72^{\circ} \mathrm{C}$ for $10 \mathrm{~min}$. The PCR condition for detection of the uvr $\mathrm{C}$ and gap A genes was initial denaturation at $94^{\circ} \mathrm{C}$ for $2 \mathrm{~min}$, followed by 35 cycles of denaturation at $94^{0} \mathrm{C}$ for $30 \mathrm{sec}$, annealing at $56^{\circ} \mathrm{C}$ for $30 \mathrm{sec}$ for gap $\mathrm{A}$ and at $52^{0} \mathrm{C}$ for $30 \mathrm{sec}$ for uvr $\mathrm{C}$, and extension at $72^{0} \mathrm{C}$ for $2 \mathrm{~min}$ with a final extension at $72^{0} \mathrm{C}$ for $5 \mathrm{~min}$.

\section{Detection of quinolones resistance (QRDR) genes}

Amplification of genes (gyr A and par C) encoding for quinolone resistance (QRDRs) was carried out by PCR. The PCR reactions were performed in $50 \mu \mathrm{l}$ volume for each isolate, with $30 \mathrm{pmol} / \mu \mathrm{l}$ of each primer and $100 \mathrm{ng}$ DNA. Conditions for the PCR were as follows: $95^{\circ} \mathrm{C}$ for $3 \mathrm{~min}, 30$ cycles of denaturation for 30 sec at $95^{\circ} \mathrm{C}$, followed by annealing of $30 \mathrm{sec}$ at $56^{\circ} \mathrm{C}$ and extension at $72^{\circ} \mathrm{C}$ for 45 sec with a final extension at $72^{\circ} \mathrm{C}$ for $10 \mathrm{~min}$. The type strain M. bovis ATCC 25523/ PG45 was used as quality control

\section{Nucleotide sequencing and sequence analysis}

PCR products were purified using the Gene Jet PCR purification kit; Fermentas (Thermo Fisher Scientific). Each purified amplicon was sequenced in both forward and reverse directions using the amplification primers (Table 1). Amplicons were sequenced in an automated sequencer (Macrogen Company 24, Gasan-dong, Geumchun-gu, Seoul 153-781, Korea). Sequence data similarity searches were analyzed by using NCBI-BLAST programme (http://www.ncbi.nlm.nih.gov/BLAST). The comparisons of obtained nucleotide sequences and their multiple alignments were performed using the BioEdit sequence alignment editor (CLUSTALX software version 7.0.9.0) (6/27/07) for multiple sequence alignment (Figure S1). Sequences were then submitted to NCBI GenBank using BankIt (http://www.ncbi.nlm.nih.gov/WebSub/?tool=genbank) under the accession numbers of: 


\section{Mycoplasma species using 16S rRNA}

MK287843.1 Mycoplasma sp. strain WASC 1 16S ribosomal RNA gene, partial sequence

Mycoplasma bovis

MK287842.1 Mycoplasma bovis strain WABC 2 16S ribosomal RNA gene, partial sequence

MK300692.1 Mycoplasma bovis strain WABC 3 16S ribosomal RNA gene, partial sequence

vsp

MK614941 Mycoplasma bovis strain WABvsp 5 vsp

MK618668 Mycoplasma bovis strain WABvsp 6 vsp

$\operatorname{par} \mathbf{C}$

\begin{tabular}{l}
\hline MK359203 Mycoplasma bovis strain WAC 4 DNA topoisomerase IV subunit A \\
\hline MK359202 Mycoplasma bovis strain WAC 3 DNA topoisomerase IV subunit A
\end{tabular}

\section{S phylogenetic tree}

16S phylogenetic tree was constructed using the online pipeline NGpyologeny.fr (Lemoine et al., 2019). Within this pipeline sequences were aligned using MUSCLE, ambiguous aligned regions were removed with GBLOCK, and a phylogenetic tree was constructed with PhyML+SMS using GTR model and bootstrap 100 times (Edgar, 2004; Talavera and Castresena, 2007; Lefort et al., 2017). The Phyogentic Tree was visualized and annotated with iTOL (letunic and Bork, 2016).

\section{Results}

\section{Prevalence of $M$. bovis in the samples recovered from lungs of camels}

Out of the 210 pneumonic lung samples, 13 (27.3\%) were recorded to be positive for putative mycoplasmas. On the other hand, infection with the organism was not detected in the apparently healthy lungs.

\section{Phenotypic virulence traits}

\section{Detection of haemolytic activities of $M$. bovis}

The effect of $M$. bovis on RBCs was tested in a liquid environment. In this assay, the RBCs formed a loose pellet. $\beta$-hemolysis would result in the disruption of the erythrocytes and the release of the red haemoglobin. We observed, however, that the erythrocytes remained intact, but noted a colour change of the blood cells from red to brown which is characteristic for $\alpha$-haemolysis resulting from a modification of haemoglobin thus they were phenotypically haemolytic.

\section{Hydrogen sulphide production}

The recorded haemolytic activities of the $13 \mathrm{M}$. bovis isolates in the presence of cysteine suggested that the bacteria produced $\mathrm{H}_{2} \mathrm{~S}$ from cysteine which in turn caused haemolysis.

\section{Biofilm formation capability}

The $M$. bovis strains were found to be weak in their ability to adhere to polystyrene multiwall plates. Very low spectrophotometric values (A560 (0.062-0.036)) were detected for these isolates that had poor adhesion and biofilm formation abilities.

\section{Antimicrobial resistance among the $M$. bovis isolates}

The antimicrobial resistance profiles of $M$. bovis isolates obtained in this study are displayed in Table 2. All isolates were susceptible to florfenicol, spiromycin and streptomycin and resistant to ciprofloxacin. Resistance 
to lincomycin, tylosin, doxycycline and erythromycin was observed at different frequencies. Table 3 indicates that there are five different combinations of antibiotics representing one to three classes with the

Macrolide erythromycin being the most represented.

Distribution of the virulence and QRDR genes in the $M$. bovis isolates

In this study, we did not observe the presence of uvr $\mathrm{C}$ andgap A virulence genes and the QRDR genes by PCR. However, we did record the presence of the $v s p$ virulence gene in 2 out of the13M. bovis isolates (Table2). Also, the par $\mathrm{C}$ gene was also present in 2/13 M. bovis isolates, while the gyr A gene was not present in any of the thirteen isolates.

Phylogentic comparison of 16S Ribosomal RNA of $M$. bovisisolates from camel in Egypt with $M$. bovis isolates recovered from different countries

From the16S Ribosomal RNA sequence we were unable to determine any differences in isolates recovered from camel in Egypt to isolates recovered from other regions of the world from cattle (Figure 1). The only difference we can infer was a single SNP which was found in isolate Mb31 from Belgium; MYC72 and MYC75 both from Hungary (Figure 1). The 16S rRNA gene sequence were indisinguishable from those isolated from cattle around the world.

Phylogentic comparison of vspA gene of M. bovis isolates from camel in Egypt with M. bovis isolates recovered from different countries

From the data published on GenBank, the isolates: MK618668.1 showed identity (100\%) to the sequence MK614941.1 (published from this study) and the published sequences HM856905.1 and HM856908.1, but showed $98.65 \%$ similarity to HM856907.1 and $98.31 \%$ similarity to HM856904.1 and $97.97 \%$ similarity to HM856906.1. (Figure 2).

\section{Discussion}

Although M. bovis is a global menace yet, there are no trade restrictions for any of the markets in Egypt presenting a trade risk. Mycoplasma bovis does not cause disease in humans and is not a notifiable disease (AHDB, 2020) although it was previously cultured from the sputum of a patient with lobar pneumonia (Madoff et al., 1979) and it is one of the major causative agents of bovine mycoplasmosis. Infection with the organism is associated with a broad range of clinical manifestations including bronchopneumonia, treatment-resistant mastitis, otitis, meningitis, and genital disorders, tenosynovitis, keratoconjunctivitis, chronic pneumonia, arthritis, polyarthritis with high morbidity and late-termabortions (Bürki et al., 2015; Hananehet al., 2018).

The disease may be dormant in an animal - causing no symptoms (Maunsell et al., 2011). In times of stress the animal may shed bacteria in milk and nasal secretions. As a result, other animals may be infected and become ill or carriers themselves (Calcutt et al., 2018). In our case, the camels are subjected to severe stress during transportation on foot covering thousands of kilometers or when they are transported by rail vehicles. Effects of transportation and movement include (FAO, 2001): stress, bruising, trampling, suffocation, heart failure, heat stroke, sun burn, bloat, poisoning, predation, dehydration, exhaustion, injuries and fighting. Although the circumstances of how or/and where camels in this study became infected are unknown, it is possible that potential infection includes the importation of live camel by vehicles which have been used for the transportation of the animals. Contact between infected and non-infected animals when it occurs in confined spaces increases, as during the transport of the camels from Aswan to Cairo by rail truck, the risk of "nose-to-nose" transmission becomes unavoidable. When the camels reach Cairo they are transported on foot to Birqash Market, the largest camel market in Egypt, where they are sold for slaughter, farm work, tourism and transport. The farm equipment are additional factors that play important roles in the spread of the disease, especially those that come into direct contact with infected animals.

In this study we have extended the arsenal of factors implicated in the pathogenicity of $M$. bovis in addition to those reported previously (Großhennig et al., 2016). The overlapping but distinct effects of $\mathrm{H}_{2} \mathrm{~S}$ indicate that the bacteria possess a set of virulence determinants that together allow the bacteria getting an efficient 
access to the host's resources. Although the production of $\mathrm{H}_{2} \mathrm{~S}$ as a virulence factor has not been observed for pathogens causing lung infections before with the exception of two studies that have reported (Großhennig et al., 2016) that $\mathrm{H}_{2} \mathrm{~S}$ is an additional factor implicated in the cytotoxicity and virulence of $M$. pneumonia and a very recent study on M. arginini (Osman et al., 2020). This is consistent with the results we obtained for $M$. bovis in this study.

One aspect of pathogenesis that warrants further comment is the ability of many Mycoplasma species to form biofilms, with $M$. bovisrepresenting one of the prolific biofilm producers among a survey of species tested (McAuliffe et al., 2006). However, the formation of biofilms by many Mycoplasma species has mainly been demonstrated in vitro (McAuliffe et al., 2006; Simmons et al., 2013; Wang et al., 2017). The role of bacterially derived biofilms in causing human disease has been known for some time (Wilson, 2001), and an increasing appreciation of biofilms in bovine mastitis is emerging (Melchior et al., 2006; Gomes et al., 2016). It is therefore plausible that biofilms elaborated by $M$. bovis may influence some aspect of the disease course or pathogenicity in camels. Unfortunately, due to the absence of the vsp gene in 11 out of the 13 isolates in this study, we were unable to compare different $M$. bovis isolates for a correlation analysis as shown by Calcutt et al. (2018) who demonstrated the biofilm production and corresponding vsp expression profile. The aforementioned ability of $M$. bovis to survive in bedding (Justice-Allen et al., 2010) may be explained by the presence of biofilms, which is important in other sand-containing environments (Whitman et al., 2014). In vitro, biofilm production conferred greater resistance to heat and desiccation than was exhibited by planktonic $M$. bovis cells (McAuliffe et al., 2006), raising the possibility that this capability may contribute to the observed environmental persistence and perhaps to chronic infection in the bovine host (Calcutt et al., 2018) which could consequently also convey this characteristic to the desert dwelling animal, the camel.

Antibiotic resistance is an ongoing one of the most pressing threats in the world. The World Health Organization recently recognised antibiotic resistance as a serious global problem, not only in terms of human health but also for the animals (both domestic and wildlife) and the environment (Gibbs, 2014). However, the role of wild animals as a reservoir of antibiotic resistant bacteria has been acquiring attention in recent years (Finley et al., 2013; Smith et al., 2014; Dias et al., 2018).

Many in vitro studies have compared the susceptibility of $M$. bovis against a range of antibiotics. Mycoplasmas are generally susceptible to antibiotics that affect protein (tetracyclines, macrolides, lincosamides, phenicols) or nucleic acid synthesis (fluoroquinolones) (Maunsell et al., 2011; Muller et al., 2019).M. bovis has developed antimicrobial resistance to many of the antimicrobial agents traditionally used in the therapy of Mycoplasma infections; in particular oxytetracyclines, tilmicosin and spectinomycin (Ayling et al., 2000; Nicholas et al., 2000; Sulyok et al., 2014; Calcutt et al., 2018). Acquired resistance to macrolides in $M$. bovis is a widely known phenomenon. Gerchman et al. (2009) reported marked differences in susceptibility profiles to tylosin in $M$. bovis from different geographical regions, including Western Canada, Israel, Britain, Hungary, Japan, USA and France (Lysnyansky and Ayling, 2016). High level of resistance to macrolides has been reported by others (Ayling et al., 2000; Rosenbusch et al., 2003; Gerchman et al., 2009; Uemura et al., 2010; Gautier-Bouchardon et al., 2014; Sulyok et al., 2014) with the indication that macrolides have lost their efficacy on mycoplasmas. Our results provide further evidence for this phenomenon with 10 isolates being resistant to erythromycin only while the other two antibiotics belonging to the Macrolides tylosin and spiramycin were on the contrary, effective in this study (Table 1).

However, in contrast to other studies that reported increased resistance to antibiotics commonly used for the therapy of Mycoplasmainfections, including tetracyclines, phenicol and lincosamide, the majority of M. bovis isolates in this study were susceptible to florfenicolor lincomycin. Heterogenic susceptibility of $M$. bovisto tetracyclines is widely reported (Gourlay et al., 1989; Ayling et al., 2000; Rosenbusch et al., 2003; Gerchman et al., 2009; Uemura et al., 2010; Gautier-Bouchardon et al., 2014). Consistent with our results, increased resistance to oxytetracycline was reported previously in the UK, The Netherlands, North America, Israel, Belgium, Hungary, Japan and France (Lysnyansky and Ayling, 2016).

Although the most effective antibiotics tested in vitro for the treatment of $M$. bovis infections were fluoroquinolones (Lysnyansky and Ayling, 2016; Ayling et al., 2000; Rosenbusch et al., 2005;Francoz et al., 2005; 
Gerchman et al., 2009; Uemura et al., 2010; Soehnlen et al., 2011; Kroemer et al., 2012; Gautier-Bouchardon et al., 2014) yet, some in vitro resistance to fluoroquinolones has also been reported (Gerchman et al., 2009). In this study all thirteen $M$. bovis isolates recovered from camels were resistant to ciprofloxacin, which is consistent with previously published data in cattle (Gerchman et al., 2009). Globally, the reports on susceptibility profiles of $M$. bovis to fluoroquinolones display extensive discrepancies that vary considerably from one country to another (Khalil et al., 2016).

M. bovis isolated from the camels in Egypt, may have been transmitted from cattle from other regions based on $16 \mathrm{~S}$ ribosomal RNA sequence data. M. bovis has been reported to be transmitted across species from cattle, camel and other livestock in Eritrea, East Africa due to inter-species herd mixing at water points, resting areas as well as due to migration and uncontrolled livestock movement (Ghebremariam et al, 2018). Egypt has also recently increased the number of cattle it has imported from other countries, mainly from Brazil, Spain, Sudan, Colombia, Hungary, The Netherlands, Italy and Uruguay (Roushdy, 2018).

Alarmingly, our research identifies widespread resistance in camel to several first-line antimicrobials used in human medicine. Our results highlight camel in the wildlife as important host reservoirs and vectors for the spread of a virulent, multidrug-resistant $M$. bovis and genetic determinants of resistance. The inability of $M$. bovis to form biofilms should decrease their persistence. Taking into account that camel isolates do not contact directly with antibiotics, the resistance observed among the studied $M$. bovis is alarming and that measures are necessary to monitor this alarming phenomenon (Lysnyansky and Ayling, 2016). This could be related to the overuse/misuse of the antibiotics in human and veterinary medicine, with a consequent spread of resistance genes to the environment.

\section{Conclusion}

To our knowledge, this work is the first study reporting $\mathrm{H}_{2} \mathrm{~S}$ as a novel potential virulence determinant of $M$. bovis isolated in Egypt. Due to the occurrence of fluoroquinolone resistance in $M$. bovis as well as increased resistance to other antibiotics, susceptibility testing of this pathogen should be implemented as a routine procedure and as a part of the diagnostic process. This study also draws attention on the increasing number of drug-resistant M. bovis, in particular in Egypt asin Europe and worldwide. The data obtained in the present study shows the weak presence of the vsp gene and the conjunctive absence of theuvr $\mathrm{C}$ gene in all field isolates tested provides evidence that the serological tests based on Vsp antigens and molecular identification depending on the uvr $\mathrm{C}$ gene used for cattle is not appropriate for testing samples recovered from camels. In addition, these potential virulence factors could not be used as candidates for drug therapy and vaccine design.

\section{Competing Interests}

The authors declare there are no competing interests.

\section{Funding}

The authors did not receive any funds

\section{Ethical Statement}

The authors confirm that the ethical policies of the journal, as noted on the journal's author guidelines page, have been adhered to and all applicable international, national, and institutional guidelines for the care and use of animals were followed.

\section{Data Availability Statement}

Data available in article supplementary material

\section{References}

AHDB, 2020. Agriculture and Horticulture Development Board, Animal Health \& Welfare, Mycoplasma bovis. Published 21 January 15, www.ahdb.org.uk 
Alberto, A., Addis, M.F., Chessa, B., Cubaddu, T., Profiti, M., Rosati, S., Ruiu , A., Pittau, M., 2006. Molecular and antigenic characterization of a Mycoplasma bovis strain causing an outbreak of infectious kerato-conjunctivitis. J. Vet. Diagn. Invest. 18, 41-51.

Ayling, R.D., Baker, S.E., Peek, M.L., Simon, A.J., Nicholas, R.A., 2000. Comparison of in vitro activity of danofloxacin, florfenicol, oxytetracycline, spectinomycin and tilmicosin against recent field isolates of Mycoplasma bovis . Vet. Rec. 146, 745-747. doi: 10.1136/vr.146.26.745.

Brown, D.R., May, M., Bradbury, J.M., Johansson, K.E., 2015. Mollicutes. Bergey's Manual of Systematics of Archaea and Bacteria.1 -8

Burki, S., Frey, J., Pilo, P., 2015. Virulence, persistence and dissemination of Mycoplasma bovis . Vet. Microbiol. 179, 15-22. doi: 10.1016/j.vetmic.2015.02.024

Calcutt, M.J., Lysnyansky, I., Sachse, K., Fox, L. K., Nicholas, R.A.J., Ayling, R.D., 2018. Gap analysis of Mycoplasma bovis disease, diagnosis and control: an aid to identify future development requirements. Transboundary and Emerging Diseases, 65(s1), 91-109. https://onlinelibrary.wiley.com/doi/full/10.1111/tbed.12860

Chavez Gonzalez, Y.R., Ros Bascunana, C., Bo elske, G., Mattson, J.G., Fernandez Molina, C., Johansson, K.E., 1995. In vitro ampliC/cation of the 16S rRNA genes from Mycoplasma bovis and Mycoplasma agalactiae by PCR. Vet. Microbiol. 47, 183-190.

CLSI, Clinical and Laboratory Standards Institute, 2012. Performance standards for antimicrobial susceptibility testing; twenty-second informational supplement. M100-S21. Wayne; CLSI.

Clyde, W.A., JR. 1964. Mycoplasma species identification based upon growth inhibition by specific antisera. J. Immunol. 92, 958-965.

Dias, C., Borges, A., Oliveira, D., Martinez-Murcia, A., Saavedra, M.J., Simoes, M., 2018, Biofilms and antibiotic susceptibility of multidrug-resistant bacteria from wild animals. PeerJ 6, e4974; DOI $10.7717 /$ peerj. 4974

Edgar, R.C., 2004. MUSCLE: multiple sequence alignment with high accuracy and high throughput.Nucleic Acids Res. 32, 1792-1797. 10.1093/nar/gkh340

Erno, H., Stipkovits, L., 1973. Bovine mycoplasmas: cultural and biochemical studies. Acta Veterinaria Scandinavica 14, 450-463.

FAO 2001. CHAPTER 6: Transport of livestock, In: Guidelines for Humane Handling, Transport and Slaughter of Livestock. Food and Agriculture Organization of the United Nations Regional Office for Asia and the Pacific, 39 Maliwan Mansion, Phra-Atit Road, Bangkok 10200, Thailand.

Finley, R.L., Collignon, P., Larsson, D.G., McEwen, S.A., Li, X.Z., Gaze, W.H., Reid-Smith, R., Timinouni, M., Graham, D.W., Topp, E., 2013. The scourge of antibiotic resistance: the important role of the environment. Clin. Infect. Dis. 57, 704-710. DOI 10.1093/cid/cit355.

Fox, L.K. 2012. Mycoplasma mastitis. Causes, transmission, and control. Vet. Clin. North Am. Food Anim. Pract. 28, 225-237. https:// doi .org/ 10 .1016/ j .cvfa .2012 .03 .007.

Francoz, D., Fortin, M., Fecteau, G., Messier, S., 2005. Determination of Mycoplasma bovis susceptibilities against six antimicrobial agents using the E test method. Vet. Microbiol. 105, 57-64. doi:10.1016/j.vetmic.2004.10.006

Freundt, E.A., Andrews, B.E., Erno, H., Kunze, M., Black, F.T., 1973. The sensitivity of Mycoplasmatales to sodium polyanetholsulfonate and digitonin. Zentralblatt fur Bakteriologie, Parasitenkunde, Infektionskrankheiten und Hygiene 225, 104-112. 
Gautier-Bouchardon, A.V., Ferre, S., Le Grand, D., Paoli, A., Gay, E., Poumarat, F., 2014. Overall Decrease in the Susceptibility ofMycoplasma bovis to Antimicrobials over the Past 30 Years in France. PLoS ONE 9(2), e87672. https://doi.org/10.1371/journal.pone.0087672

Gerchman, I., Levisohn, S., Mikula, I., Lysnyansky, I., 2009. In vitro antimicrobial susceptibility of Mycoplasma bovis isolated in Israel from local and imported cattle. Vet. Microbiol. 137, 268-275. doi:10.1016/j.vetmic.2009.01.028

Ghebremariam, M.K., Michel, A.L., Vernooij, J.C.M., Nielen, M., Rutten, V.P.M.G., 2018. Prevalence of bovine tuberculosis in cattle, goats, and camels of traditional livestock raising communities in Eritrea. BMC Vet. Res. 14(1), 73. doi: 10.1186/s12917-018-1397-0.

Gibbs, E.P., 2014. The evolution of One Health: a decade of progress and challenges for the future. Vet. Rec. 174, 85-91. DOI 10.1136/vr.g143.

Gille, L., Callens, J., Supre, K., Boyen, F., Haesebrouck, F., Driessche, L. van, Leenen, K. van, Deprez, P., Pardon, B., 2018. Use of a breeding bull and absence of a calving pen as risk factors for the presence of Mycoplasma bovis in dairy herds. J. Dairy Sci. 101(9), 8284-8290. doi: 10.3168/jds.2018-14940

Gomes, F., Saavedra, M.J., Henriques, M., 2016. Bovine mastitis disease/pathogenicity: Evidence of the potential role of microbial biofilms. Pathog. Dis. 74(3), Pii:ftw006. https://doi.org/10. 1093/femspd/ftw006

Gourlay, R.N., Thomas, L.H., Wyld, S.G., Smith, C.J., 1989. Effect of a new macrolide antibiotic (tilmicosin) on pneumonia experimentally induced in calves by Mycoplasma bovis and Pasteurella haemolytica. Res. Vet. Sci. 47(1), 84-89.

Grosshennig, S., Ischebeck, T., Gibhardt, J., Busse, J., Feussner, I., Stulke, J., 2016. Hydrogen sulfide is a novel potential virulence factor of $M$ y c o p l a s m a p n e u $m$ o nia e : characterization of the unusual cysteine desulfurase/desulfhydrase HapE. Mol. Microbiol. 100(1), 42-54. doi: 10.1111/mmi.13300

Haines, D.M., Martin, K.M., Clark, E.G., Jim, G.K., Janzen, E.D., 2001. The immunohistochemical detection of Mycoplasma bovis and bovine viral diarrhea virus in tissues of feedlot cattle with chronic, unresponsive respiratory disease and/or arthritis. Can. Vet. J. 42(11), 857-860.

Hananeh, W.M., Momani, W.M.A., Ababneh, M.M., Abutarbush, S.M., 2018.Mycoplasma bovis arthritis and pneumonia in calves in Jordan: An emerging disease. Vet. World 11(12), 1663-1668. doi: 10.14202/vetworld.2018.1663-1668.

Hirst, K.K., 2020. "The Origin Histories of Dromedary and Bactrian Camels." ThoughtCo, Feb. 11, 2020, thoughtco.com/origin-histories-dromedary-bactrian-camels-169366.

Howard, W.W., Ricardo, F.C., Lioyd, H.L., 1994. Textbook of Mycoplasmosis in Animals, Laboratory Diagnosis, AVLD, 1st edition.

Justice-Allen, A., Trujillo, J., Corbett, R., Harding, R., Goodell, G., Wilson, D., 2010. Survival and replication of Mycoplasma species in recycled bedding sand and association with mastitis on dairy farms in Utah. J. Dairy Sci. 93, 192-202. https://doi.org/10.3168/ jds.2009-2474

Khalil, D., Becker, C.A.M., Tardy, F., 2016. Alterations in the Quinolone Resistance-Determining Regions and Fluoroquinolone Resistance in Clinical Isolates and Laboratory-Derived Mutants of Mycoplasma bovis : Not All Genotypes May Be Equal. Appl. Environ. Microbiol. 82(4), 1060-1068. doi: 10.1128/AEM.03280-15.

Kroemer, S., Galland, D., Guerin-Faublee, V., Giboin, H., Woehrle-Fontaine, F., 2012. Survey of marbofloxacin susceptibility of bacteria isolated from cattle with respiratory disease and mastitis in Europe. Vet. Rec. 170(2), 53. doi:10.1136/vr.100246

Lauerman, L.H., 1994. Mycoplasmas of the Bovine Respiratory Tract. In: Mycoplasmosis in Animals: Laboratory Diagnosis, Whitford, H.W., R.F. Rosenbusch and L.H. Lauerman (Eds.). Iowa State University Press, Ames, Iowa, pp: 50-56. 
Lefort, V., Longueville, J. E., Gascuel, O., 2017. SMS: Smart Model Selection in PhyML. Molecular biology and evolution, 34(9), 2422-2424. doi:10.1093/molbev/msx149

Lemoine, M., Moens, T., Vafeiadou, A.M., Bezerra, L.A.V., Lana, P., 2019. Resource utilization of puffer fish in a subtropical bay as revealed by stable isotope analysis and food web modeling. Mar. Ecol. Prog. Ser. 626, 161-175. https://doi.org/10.3354/meps13045

Letunic, I., Bork, P., 2016. Interactive tree of life (iTOL) v3: an online tool for the display and annotation of phylogenetic and other trees. Nucleic Acids Res. 44(W1), W242-W245. doi:10.1093/nar/gkw290

Linnaeus, C., 1758. Systema Naturae Per Regna Tria Naturae( 10thed.). Stockholm, Sweden: Laurentius Salvius. p. 65.Archivedfrom the original on 2018-06-17. Retrieved 2018-02-20.

Lysnyansky, I., Ayling, R.D., 2016.Mycoplasma bovis : Mechanisms of Resistance and Trends in Antimicrobial Susceptibility. Front. Microbiol. 27;7: 595. doi: 10.3389/fmicb.2016.00595.

Lysnyansky, I., Mikula, I., Gerchman, I., Levisohn, S., 2009. Rapid Detection of a Point Mutation in the parC Gene Associated with Decreased Susceptibility to Fluoroquinolones in Mycoplasma bovis. Antimicrob. Agents Chemother. 53, 4911-4914.

Madoff, S., Pixley, B.Q., DelGiudice, R.A., Moellering, R.C. Jr., 1979. Isolation of Mycoplasma bovis from a patient with systemic illness. J. Clin. Microbiol. 9(6), 709-11. PMID: 387817; PMCID: PMC275384.

Maunsell, F.P., Woolums, A.R., Francoz, D., Rosenbusch, R.F., Step, D.L., Wilson, D.J., Janzen, E.D., 2011. Mycoplasma bovis Infections in Cattle. J. Vet. Intern. Med. 25, 772-783

McAuliffe, L., Ellis, R.J., Miles, K., Ayling, R.D., Nicholas, R.A.J., 2006. Biofilm formation by Mycoplasma species and its role in environment persistence and survival. Microbiology, 152, 913-922. https://doi.org/10.1099/mic.0.28604-0

Melchior, M.B., Vaarkamp, H., Fink-Gremmels, J., 2006. Biofilms: A role in recurrent mastitis infections? The Vet. J. 171, 398- 407. https://doi.org/10.1016/j.tvjl.2005.01.006

Muller, E.E., Mahlangu, M.P., Lewis, D.A., Kularatne, R.S. 2019. Macrolide and fluoroquinolone resistanceassociated mutations in Mycoplasma genitalium in Johannesburg, South Africa, 2007-2014. BMC Infect. Dis. 19, 148. https://doi.org/10.1186/s12879-019-3797-6

Napp, S., Chevalier, V., Busquets, N., Calistri, P., Casal, J., Attia, M., Elbassal, R., Hosni, H., Farrag, H., Hassan, N., Tawfik, R., Abd Elkader, S., Bayomy, S., 2018. Understanding the legal trade of cattle and camels and the derived risk of Rift Valley Fever introduction into and transmission within Egypt. PLoS Negl. Trop. Dis. 12(1), e0006143. doi: 10.1371/journal.pntd.0006143.

Nicholas, R.A., B.E., Ayling, R.D., Stipkovits, L., 2000.Mycoplasma infection in growing cattle. Cattle Pract. 8, 115-118.

Nicholas, R.A.J., Ayling, R.D., 2003. Mycoplasma bovis: disease, diagnosis, and control. Res. Vet. Sci. 74(2), 105-112. doi: 10.1016/S0034-5288(02)00155-8

\section{Nicholas, R.A.J., 2011. Bovine mycoplasmosis: silent and deadly. Vet. Rec. 168, 459-462.}

Nigel French., 2019. What is Mycoplasma bovis ? Biosecurity New Zealand, Protection \& Response, Last reviewed: 27 Jun 2019, the director of the NZ Food Safety Science \& Research Centre, and a professor of food safety at Massey).

Perez-Casal, J., Prysliak, T., 2007. Detection of antibodies against the Mycoplasma bovis glyceraldehyde-3phosphate dehydrogenase protein in beef cattle. Microb. Pathog. 43, 189-197 
Pritchard, R.E., Prassinos, A.J., Osborne, J.D., Raviv, Z., Balish, M.F., 2014.Reduction of Hydrogen Peroxide Accumulation and Toxicity by a Catalase from Mycoplasma iowae. PLoS ONE 9(8), e105188. https://doi.org/10.1371/journal.pone.0105188RAP Publication 2001/4

Register, K.B., Boatwright, W.D., Gesy, K.M., Thacker, T.C., Jelinski, M.D., 2018. Mistaken identity of an open reading frame proposed for PCR-based identification of Mycoplasma bovis and the effect of polymorphisms and insertions on assay performance J. Vet. Diagn. Invest. 30 (4), 637-641

Roess, A., Carruth, L., Mann, M., Kabbash, I., Melaku, S., Atia, M., Mohamed, M., Bansal, S., Lahm, S., Terefe, Y., Salman, M., 2015. Livestock movement and emerging zoonotic disease outbreaks: applying ecological, network, and sociocultural theories to assess the risk of Middle East respiratory syndrome from camel trade in Ethiopia and Egypt. The Lancet Global health 3, Supplement 1, S26 https://doi.org/10.1016/S2214109X(15)70145-2

Rosenbusch, R.F., Kinyon, J.M., Apley, M., Funk, N.D., Smith, S., Hoffman, L.J., 2005. In vitro antimicrobial inhibition profiles of Mycoplasma bovis isolates recovered from various regions of the United States from 2002 to 2003. J. Vet. Diagn. Invest. 17(5), 436-441. doi:10.1177/104063870501700505

Roushdy, S., 2018. Livestock and Products Annual 2018. Date 9/19/2018 GAIN REPORT Number: EG18021 Global Agricultural Information Network.

Sharma, S., Markham, P.F., Browning, G.F., 2014. Genes Found Essential in Other Mycoplasmas Are Dispensable in Mycoplasma bovis . PLoS ONE 9(6), e97100. doi:10.1371/journal.pone.0097100.

Simmons, W.L., Daubenspeck, J.M., Osborne, J.D., Balish, M.F., Waites, K.B., Dybvig, K., 2013. Type 1 and type 2 strains of Mycoplasma pneumoniae form different biofilms. Microbiology 159, 737-747. https://doi.org/10.1099/mic.0.064782-0

Smith, S., Wang, J., Fanning, S., McMahon, B.J., 2014. Antimicrobial resistant bacteria in wild mammals and birds: a coincidence or cause for concern? Irish Vet. J. 67, Article 8. DOI 10.1186/2046-0481-67-8.

Soehnlen, M.K., Kunze, M.E., Karunathilake, K.E., Henwood, B.M., Kariyawasam, S., Wolfgang, D.R., Jayarao, B.M., 2011. In vitro antimicrobial inhibition of Mycoplasma bovisisolates submitted to the Pennsylvania Animal Diagnostic Laboratory using flow cytometry and a broth microdilution method. J. Vet. Diagn. Invest. 23(3), 547-551.

Subramaniam, S., Bergonier, D., Poumarat, F., Capaul, S., Schlatter, Y., Nicolet, J., Frey, J., 1998. Species identiC/cation of Mycoplasma bovis and Mycoplasma agalactiae based on the uvr C genes by PCR. Mol. Cell. Probes 12(3), 161-169.

Sulyok, K.M., Kreizinger, Z., Fekete, L., Hrivnak, V., Magyar, T., Janosi, S., Schweitzer, N., Turcsanyi, I., Makrai, L., Erdelyi, K., Gyuranecz, M., 2014. Antibiotic susceptibility profiles of Mycoplasma bovis strains isolated from cattle in Hungary, Central Europe. BMC Vet. Res. 10, 256. doi: 10.1186/s12917-014-0256-x.

Talavera, G., Castresana, J., 2007. Improvement of Phylogenies after Removing Divergent and Ambiguously Aligned Blocks from Protein Sequence Alignments. Systematic Biology56(4), 564-577.

Thomas, A., Ball, H., Dizzier, I., Trolin, A., Bell, C., Mainil, J., Linden, A., 2002. Isolation of Mycoplasma species from the lower respiratory tract of healthy cattle and cattle with respiratory disease in Belgium. Vet. Rec. 151, 472-476. doi:10.1136/vr.151.16.472

Thomas, A., Nicolas, C., Dizier, I., Mainil, J., Linden, A., 2003. Antibiotic susceptibilities of recent isolates of Mycoplasma bovis in Belgium. Vet. Rec. 153(14), 428-431. doi:10.1136/vr.153.14.428

Uemura, R., Sueyoshi, M., Nagatomo, H., 2010. Antimicrobial susceptibilities of four species of Mycoplasma isolated in 2008 and 2009 from cattle in Japan. J. Vet. Med. Sci. 72(12), 1661-1663. doi:10.1292/jvms.100165 
Van Kuppeveld, F.J.M., Johansson, K.E., Galama, J.M.D., Kissing, J.G., Bolske, G., Van Der Logt, J.T.M., Melchers, W.J.G., 1994. Detection of Mycoplasma contamination in cell cultures by a MycoplasmaGroupSpecific PCR. Appl. Environ. Microbiol. 60, 149-152.

Waites, K.B., Lysnyansky, I., Bebear, C.M., $2014 . \quad$ Emerging antimicrobial resistanceinmycoplasmasofhumansandanimals,p289-322.In Browning, G.F., Citti, C. (ed), Mollicutesmolecular biology and pathogenesis. Caister Academic Press, Norfolk, United Kingdom.

Wang, Y., Yi, L., Zhang, F., Qiu, X., Tan, L., Yu, S., Xiangchao Cheng, Ding, C., 2017. Identification of genes involved in Mycoplasma gallisepticum biofilm formation using mini-Tn4001-SGM transposon mutagenesis. Vet. Microbiol. 198, 17 -22. https://doi.org/10.1016/j.vetmic.2016. 11.021

Whitman, R., Harwood, V. J., Edge, T. A., Nevers, M., Byappanahalli, M., Vijayavel, K., Solo-Gabriele, H. M. 2014. Microbes in beach sands: Integrating environment, ecology and public health. Reviews in Environmental Science \& Biotechnology, 13, 329-368. https://doi.org/ 10.1007/s11157-014-9340-8 m

Wilson, M., 2001. Bacterial biofilms and human disease. Science Progress, 84, 235-254. https://doi.org/10.3184/003685001783238998

Yleana, R., Chavez, G., Carlos, R.B., Goran, B., Jens, G.M., Carmen, F., Molina, K., Erik, J., 1995. In vitro amplification of the $16 \mathrm{~S}$ r RNA genes from Mycoplasma bovis and Mycoplasma agalactiae by PCR. Vet. Microbiol., 47, 183-190.

Table 1. Oligonucleotide primers used for detection of Mycoplasma spp., M. bovis, M. bovis virulence genes and quinolones resistance (QRDR) genes

\begin{tabular}{|c|c|c|c|}
\hline References & $\mathrm{bp}$ & Sequence & Target \\
\hline $\begin{array}{l}\text { Chavez Gonzalez et al. } \\
(1995)\end{array}$ & 1000 & $\begin{array}{l}\text { 5/- AGA CTC CTA } \\
\text { CGG GAG GCA GCA } \\
-3^{/} 5^{/}-\text {ACT AGC GAT } \\
\text { TCC GAC TTC ATG }-3 /\end{array}$ & $\begin{array}{l}\text { 16SrRNA. For } \\
\text { Mycoplasma }\end{array}$ \\
\hline $\begin{array}{l}\text { VanKuppeveldet al. } \\
\text { (1994) }\end{array}$ & 280 & $\begin{array}{l}5 /- \\
\text { GGGAGCAAACAGGATA } \\
3 / \\
5 /- \\
\text { TGCACCATCTGTCACT } \\
3 /\end{array}$ & $\begin{array}{l}\text { Mycoplasma group- } \\
\text { GsptedificCT- } \\
\text { TTGTTAACCTC- }\end{array}$ \\
\hline Yleanaet al. (1995) & 360 & $\begin{array}{l}\text { 5/- CCT TTT AGA } \\
\text { TTGGGATAGCGGATG- } \\
\text { 3/5/- } \\
\text { CCGTCAAG- } \\
\text { GTAGCGTCAT } \\
\text { TTCCTAC-3/ }\end{array}$ & M.bovis \\
\hline Subramaniamet al.(1998) & 1626 & $\begin{array}{l}5 '- \\
\text { TTACGCAAGAGAATGC } \\
3 \text { ' } \\
5 \text { '- } \\
\text { TAGGAAAGCACCCTAT' } \\
3\end{array}$ & $\begin{array}{l}\text { Virulence genes } \\
\text { uvrC } \\
\text { CTCA- } \\
\text { GAT- }\end{array}$ \\
\hline
\end{tabular}




\begin{tabular}{|c|c|c|}
\hline References & bp & Sequence \\
\hline Perez-Casal et al. (2007) & 1007 & $\begin{array}{l}\text { 5'- } g a p \text { A } \\
\text { ATAGGAGGATCCAAAAGAGTCGCTATCAATGGT' } \\
3 \text { ', } \\
\text { 5'- } \\
\text { GGAAATGGTACCTTACTTAGTTAGTTTAGCAAAG } \\
\text { 3' }\end{array}$ \\
\hline Alberto et al. (2006) & 400 & $\begin{array}{l}\text { 5/- } v s p \\
\text { CTTGGATCAGTGGCTTCATTAGC- } \\
3 / \\
\text { 5/- } \\
\text { GTCATCATGCGGAATTCTTGGGT- } \\
3 /\end{array}$ \\
\hline $\begin{array}{l}\text { Lysnyansky et al. } \\
(2009)_{--}\end{array}$ & 531 & $\begin{array}{l}\text { QRDR genes } \\
\text { 5'- } g y r A \\
\text { GACGAATCATCTAGCGAG- } \\
3 ' \\
\text { ''- } \\
\text { GCCTTCTAGCATCAAAGTAGC- } \\
3 '\end{array}$ \\
\hline $\begin{array}{l}\text { Lysnyansky et al. } \\
(2009)_{--}\end{array}$ & 488 & $\begin{array}{l}\text { 5'- } \quad \text { parC } \\
\text { GAGCAACAGTTAAACGATTTG- } \\
3 ' \\
5^{\prime}- \\
\text { GGCATAACAACTGGCTCTT- } \\
3 \text { '. }\end{array}$ \\
\hline
\end{tabular}

Table 2. Investigation of phenotypic antibacterial resistance, phenotypic virulence traits, virulence and Fluoroquinolone Resistance genes in $M$. bovis species isolated from camel pneumonic lungs

Mycoplasma

PhenotPhienotPhienotPhirenotypic

Vir- Vir- Vir- Vir-

u- $\quad$ u- $\quad$ u- $\mathbf{u}-$

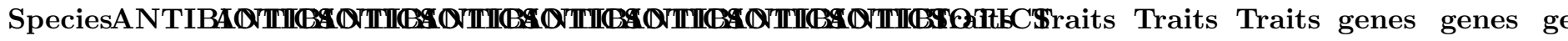

\begin{tabular}{|c|c|c|c|c|c|c|c|c|c|c|c|c|c|c|c|}
\hline \multirow[b]{2}{*}{ bovis } & \multicolumn{11}{|c|}{ 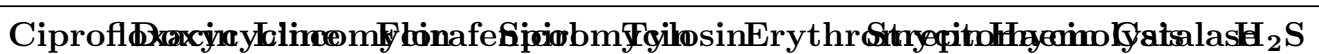 } & \multicolumn{2}{|c|}{ Biofilmvsp } & \multirow{2}{*}{ uvr $\mathbf{C}$} & \\
\hline & $\mathrm{R}$ & $\mathrm{S}$ & $\mathrm{S}$ & $\mathrm{S}$ & $\mathrm{S}$ & $\mathrm{I}$ & $\mathrm{R}$ & $\mathrm{S}$ & + & + & + & 0.037 & - & & \\
\hline bovis & $\mathrm{R}$ & $\mathrm{S}$ & $\mathrm{S}$ & $\mathrm{S}$ & $\mathrm{S}$ & $\mathrm{S}$ & $\mathrm{R}$ & $\mathrm{S}$ & + & - & + & 0.057 & - & - & - \\
\hline bovis & $\mathrm{R}$ & $\mathrm{S}$ & $\mathrm{R}$ & $\mathrm{S}$ & $\mathrm{S}$ & $\mathrm{S}$ & $\mathrm{S}$ & $\mathrm{S}$ & + & - & + & 0.056 & - & - & - \\
\hline bovis & $\mathrm{R}$ & $\mathrm{R}$ & $\mathrm{I}$ & $\mathrm{S}$ & $\mathrm{S}$ & $\mathrm{S}$ & $\mathrm{R}$ & $\mathrm{S}$ & + & - & + & 0.055 & - & - & - \\
\hline bovis & $\mathrm{R}$ & $\mathrm{S}$ & $\mathrm{S}$ & $\mathrm{S}$ & $\mathrm{S}$ & $\mathrm{S}$ & $\mathrm{S}$ & $\mathrm{S}$ & + & - & + & 0.055 & + & - & - \\
\hline bovis & $\mathrm{R}$ & $\mathrm{S}$ & $\mathrm{R}$ & $\mathrm{S}$ & $\mathrm{S}$ & $\mathrm{S}$ & $\mathrm{S}$ & $\mathrm{S}$ & + & - & + & 0.062 & - & - & - \\
\hline bovis & $\mathrm{R}$ & $\mathrm{S}$ & $\mathrm{I}$ & $\mathrm{S}$ & $\mathrm{S}$ & $\mathrm{I}$ & $\mathrm{R}$ & $\mathrm{S}$ & + & + & + & 0.056 & - & - & - \\
\hline bovis & $\mathrm{R}$ & $\mathrm{R}$ & $\mathrm{S}$ & $\mathrm{S}$ & $\mathrm{S}$ & $\mathrm{S}$ & $\mathrm{R}$ & $\mathrm{S}$ & + & - & + & 0.038 & - & - & - \\
\hline bovis & $\mathrm{R}$ & $\mathrm{R}$ & $\mathrm{S}$ & $\mathrm{S}$ & $\mathrm{S}$ & $\mathrm{S}$ & $\mathrm{R}$ & $\mathrm{S}$ & + & - & + & 0.057 & + & - & - \\
\hline bovis & $\mathrm{R}$ & $\mathrm{S}$ & $\mathrm{S}$ & $\mathrm{S}$ & $\mathrm{S}$ & $\mathrm{S}$ & $\mathrm{R}$ & $\mathrm{S}$ & + & - & + & 0.054 & - & - & - \\
\hline
\end{tabular}


Mycoplasma

\section{PhenotPpienotPpirenotPpirenotypic}

Vir- Vir- Vir- Vir-

u- u- u- u-

\begin{tabular}{llllllllllllll}
\hline bovis & $\mathrm{R}$ & $\mathrm{S}$ & $\mathrm{S}$ & $\mathrm{S}$ & $\mathrm{S}$ & $\mathrm{S}$ & $\mathrm{R}$ & $\mathrm{S}$ & + & - & + & 0.060 & - \\
bovis & $\mathrm{R}$ & $\mathrm{S}$ & $\mathrm{S}$ & $\mathrm{S}$ & $\mathrm{S}$ & $\mathrm{S}$ & $\mathrm{R}$ & $\mathrm{S}$ & + & - & + & 0.036 & - \\
bovis & $\mathrm{R}$ & $\mathrm{S}$ & $\mathrm{S}$ & $\mathrm{S}$ & $\mathrm{S}$ & $\mathrm{S}$ & $\mathrm{R}$ & $\mathrm{S}$ & + & - & + & 0.057 & - \\
\hline
\end{tabular}

Table 3. The antimicrobial resistance combinations of $M$. bovis to various antibiotics

\begin{tabular}{|c|c|c|c|}
\hline Antibiotics (Class) & $\begin{array}{l}n=\text { resistant } \\
\text { antibiotics }\end{array}$ & $n=$ antibiotic classes & $n=$ of isolates \\
\hline $\begin{array}{l}\text { Ciprofloxacin } \\
\text { (Fluoroquinolone) }\end{array}$ & 1 & 1 & 13 \\
\hline $\begin{array}{l}\text { Doxycycline } \\
\text { (Tetracycline) }\end{array}$ & 1 & 1 & 3 \\
\hline $\begin{array}{l}\text { Lincomycin } \\
\text { (Lincosamide) }\end{array}$ & 1 & 1 & 4 \\
\hline Tylosin (Macrolide) & 1 & 1 & 2 \\
\hline $\begin{array}{l}\text { Erythromycin } \\
\text { (Macrolide) }\end{array}$ & 1 & 1 & 10 \\
\hline $\begin{array}{l}\text { Doxycycline, } \\
\text { Lincomycin } \\
\text { (Tetracycline, } \\
\text { Lincosamide) }\end{array}$ & 2 & 2 & 1 \\
\hline $\begin{array}{l}\text { Erythromycin,Doxycycline } \\
\text { (Macrolide, } \\
\text { Tetracycline) }\end{array}$ & 2 & 2 & 2 \\
\hline $\begin{array}{l}\text { Erythromycin, Tylosin } \\
\text { (Macrolide) }\end{array}$ & 2 & 1 & 2 \\
\hline $\begin{array}{l}\text { Erythromycin, } \\
\text { Doxycycline, } \\
\text { Lincomycin (Macrolide, } \\
\text { Tetracycline, } \\
\text { Lincosamide) }\end{array}$ & 3 & 3 & 1 \\
\hline $\begin{array}{l}\text { Erythromycin, Tylosin, } \\
\text { Lincomycin (Macrolide, } \\
\text { Lincosamide) }\end{array}$ & 3 & 2 & 1 \\
\hline
\end{tabular}

\section{Hosted file}

image1.emf available at https://authorea.com/users/356877/articles/479647-hydrogen-sulphidean-avant-garde-potential-virulence-factor-of-mycoplasma-bovis-isolated-from-thelungs-of-the-camelus-dromedarius-exhibiting-silent-pneumonia-virulence-antimicrobialresistance-and-phylogeny 
Figure 1. Phylogenetic analysis of 16S ribosomal RNA for camelMycoplasma sequences among isolates in this study.

Red are the isolates of the present investigation

\section{Hosted file}

image2.emf available at https://authorea.com/users/356877/articles/479647-hydrogen-sulphidean-avant-garde-potential-virulence-factor-of-mycoplasma-bovis-isolated-from-thelungs-of-the-camelus-dromedarius-exhibiting-silent-pneumonia-virulence-antimicrobialresistance-and-phylogeny

Figure 2. Phylogenetic analysis of vspAgene sequences among isolates in this study. M. bovis strain isolated in this study. 